\title{
Exclusion of chromosome 9 helps to identify mild variants of acromesomelic dysplasia Maroteaux type
} Laurence Faivre, Martine Le Merrer, André Megarbane, Brigitte Gilbert, Geert Mortier,
Veronica Cusin, Arnold Munnich, Pierre Maroteaux, Valérie Cormier-Daire

\begin{abstract}
Département de Génétique, Hôpital des Enfants Malades, 149 rue de Sèvres, 75015 Paris, France L Faivre

M Le Merrer

V Cusin

A Munnich

P Maroteaux

V Cormier-Daire

Unité de Génétique, Université Saint Joseph, Beirut, Lebanon

A Megarbane

Service de Pédiatrie,

Abstract

Acromesomelic dysplasia Maroteaux type (AMDM) is an autosomal recessive disorder belonging to the group of acromesomelic dysplasias. AMDM is characterised by severe dwarfism with shortening of the middle and distal segments of the limbs. An AMDM gene has recently been mapped to human chromosome 9p13-q12 by homozygosity mapping in four consanguineous families. Here, we show linkage of the disease gene to chromosome 9p13-q12 in four of five consanguineous AMDM families and its exclusion in a fifth family with two children affected with a mild form of the disease. This study suggests that genetic heterogeneity accounts for the variable clinical and radiological severity of AMDM.

(F Med Genet 2000;37:52-54)
\end{abstract} Hôpital Universitaire Dupuytren, Limoges, France

B Gilbert

Department of

Genetics, Gent

University, Gent,

Belgium

G Mortier

Correspondence to:

Dr Munnich

Revised version received 18 May 1999

Accepted for publication

5 August 1999
Keywords: acromesomelic dysplasia Maroteaux type; acromesomelic dysplasias; homozygosity mapping; chromosome 9

First described by Maroteaux in $1971,{ }^{1}$ AMDM is an autosomal recessive disorder characterised by severe dwarfism (height below $120 \mathrm{~cm}$ ) with shortening of the middle and distal segments of the limbs. This condition is usually diagnosed at birth and becomes more obvious in the first two years of life. $X$ rays show short, broad fingers, square, flat feet, and shortening of the long bones (particularly the forearms). The radius is bowed, the ulna is shorter than the radius, and its distal end is occasionally hypoplastic. The skull is dolichocephalic and a shortness of the trunk, with decreased vertebral height and narrowing of the lumbar interpedicular distances, is consistently observed. The facial appearance and intelligence are normal. ${ }^{2} \mathrm{AMDM}$ is clinically and radiologically distinct from, and less severe than, the two other autosomal recessive acromesomelic dysplasias (AMD), namely HunterThompson type and Grebe type $\mathrm{AMD}^{3}{ }^{4}$ (table 1). The two disorders have been ascribed to mutations in the cartilage derived morphogenetic protein 1 (CDMP1) gene on human chromosome 20q. ${ }^{56}$

Recently, Kant et al reported the mapping of a gene for AMDM to human chromosome 9p13-q12 by homozygosity mapping in four inbred families. All four families were consistent with mapping of the disease gene to the 6.9 cM interval defined by loci D9S1853 and D9S1874. This observation supports the view that typical AMDM is genetically distinct from the other two autosomal recessive AMDs.

We have recently observed two sibs born to first cousin Lebanese parents (birth length 44 and $47 \mathrm{~cm}$ ) with clinical and radiological features typical of AMDM, including short, broad extremities, short middle long bones, and the ulna shorter than the radius (fig 1B). However, the disease was slightly less severe than typical AMDM. Indeed, growth failure was moderate ( -3 and -2.5 SD respectively), shortening of the extremities was milder, and

Table 1 Clinical profile of autosomal recessive acromesomelic dysplasias (AMD) and comparison with the mild AMD Maroteaux type variant

\begin{tabular}{|c|c|c|c|c|c|}
\hline & & Grebe type & Hunter-Thompson type & Maroteaux type, classical & Maroteaux type, mild \\
\hline \multirow[t]{4}{*}{ Clinical features } & Adult size & $100 \mathrm{~cm}$ & $100-130 \mathrm{~cm}$ & $120 \mathrm{~cm}$ & $\begin{array}{l}?(-2.5 \text { to }-3 \mathrm{SD} \text { at } \\
\text { age } 4)\end{array}$ \\
\hline & Long bones & $\begin{array}{l}\text { Severely shortened and } \\
\text { deformed }\end{array}$ & $\begin{array}{l}\text { Shortening progression proximal } \\
\text { to distal, large joint dislocations }\end{array}$ & $\begin{array}{l}\text { Shortening of middle } \\
\text { and distal segments }\end{array}$ & $\begin{array}{l}\text { Shortening of middle } \\
\text { and distal segments }\end{array}$ \\
\hline & \multirow[t]{2}{*}{ Hands and feet } & \multirow{2}{*}{$\begin{array}{l}\text { Ball shaped fingers, occasional } \\
\text { polydactyly, possibly absent } \\
\text { joints }\end{array}$} & Severely affected & \multirow{2}{*}{$\begin{array}{l}\text { Short and broad } \\
\text { fingers without fusions }\end{array}$} & \multirow{2}{*}{$\begin{array}{l}\text { Short and broad } \\
\text { fingers }\end{array}$} \\
\hline & & & Normal distal phalanges & & \\
\hline \multirow[t]{3}{*}{$\begin{array}{l}\text { Radiological } \\
\text { features }\end{array}$} & Long bones & $\begin{array}{l}\text { Short femoral neck, absent tibial } \\
\text { and fibular diaphyses, } \\
\text { hypoplasia of the ulna, } \\
\text { malformed radial head }\end{array}$ & $\begin{array}{l}\text { Bowing of the radius, hypoplastic } \\
\text { femoral condyles }\end{array}$ & $\begin{array}{l}\text { Ulna shorter than } \\
\text { radius, bowing of the } \\
\text { radius }\end{array}$ & $\begin{array}{l}\text { Ulna shorter than } \\
\text { radius }\end{array}$ \\
\hline & Hands and feet & $\begin{array}{l}\text { Fusion of carpal and tarsal } \\
\text { bones, absence of several } \\
\text { metacarpal and metatarsal } \\
\text { bones, absence of proximal and } \\
\text { middle phalanges }\end{array}$ & $\begin{array}{l}\text { Single phalangeal bone on digit } 5 \text {, } \\
\text { abnormally shaped carpal bones }\end{array}$ & $\begin{array}{l}\text { Short and broad } \\
\text { phalanges, metacarpal } \\
\text { and metatarsal bones }\end{array}$ & $\begin{array}{l}\text { Short and broad } \\
\text { phalanges, metacarpal } \\
\text { and metatarsal bones }\end{array}$ \\
\hline & $\begin{array}{l}\text { Vertebral } \\
\text { abnormalities }\end{array}$ & Absent & Absent & Present & Minor \\
\hline \multirow[t]{2}{*}{ Molecular findings } & Mapping & $20 \mathrm{q} 11.2$ & $20 \mathrm{q} 11.2$ & $9 \mathrm{p} 13-\mathrm{q} 12$ & Unknown \\
\hline & Mutations & $\begin{array}{l}\text { Homozygous missense mutation } \\
\text { in } C D M P-1 \text { (G1199A) }\end{array}$ & $\begin{array}{l}\text { Homozygous } 22 \mathrm{bp} \text { tandem } \\
\text { duplication, frameshift mutation }\end{array}$ & - & - \\
\hline
\end{tabular}




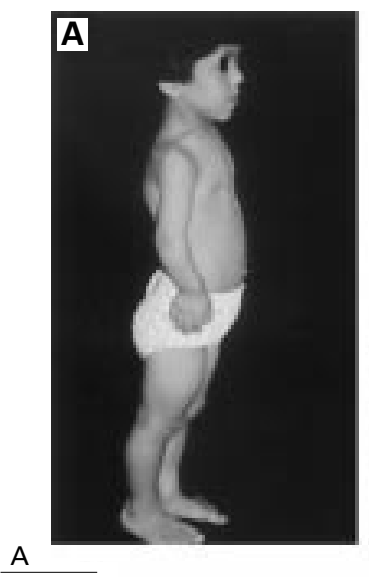

A

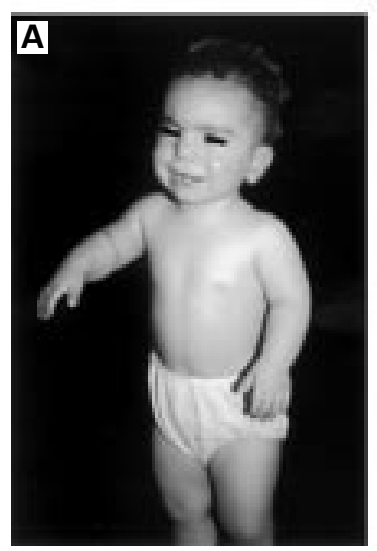

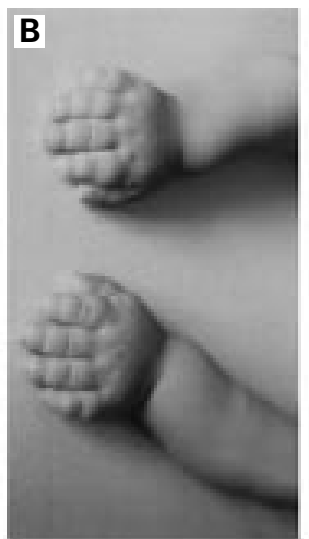
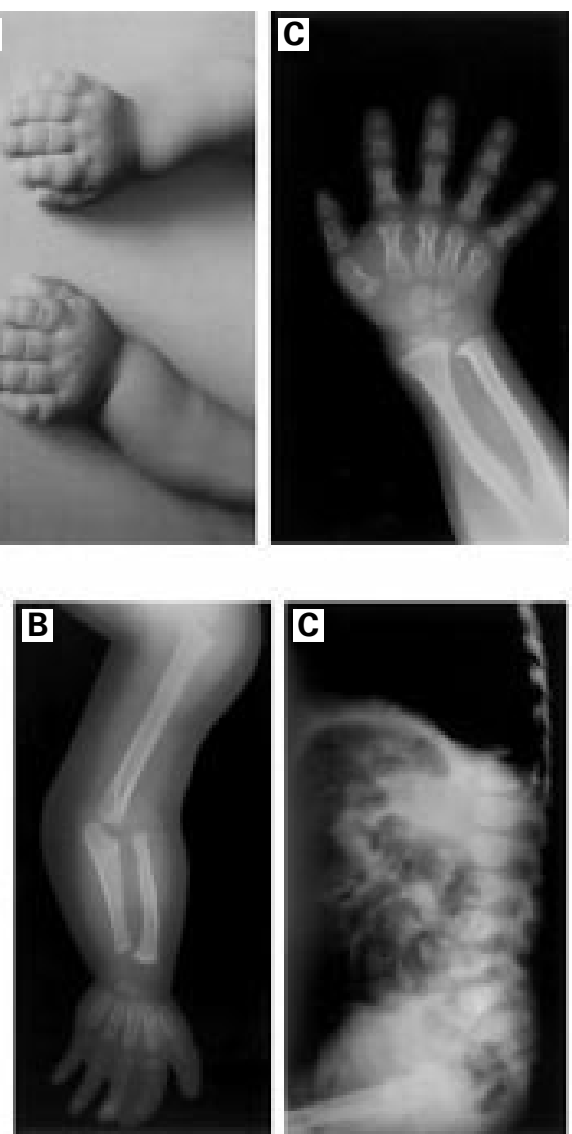

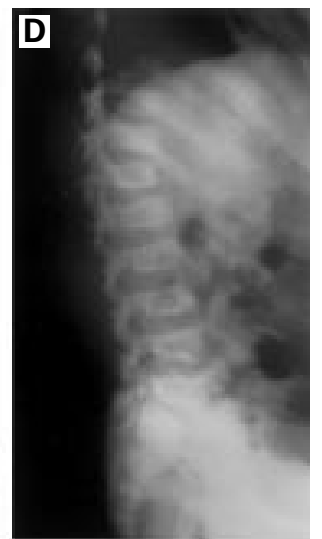

D

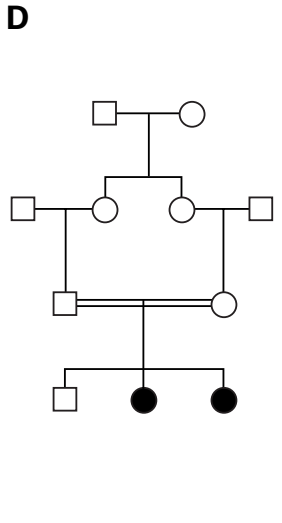

Figure 1 (Top row) Clinical and radiological features of a patient with classical AMDM aged 6 (photographs reproduced with permission). (Bottom row) Clinical and radiological features of a patient with mild AMDM. (A) Patient at the age of 3. Note that the shortening of the forearms and extremities is less obvious than in fig $1 A$ (top row). ( $B, C$ ) $X$ rays at the age of 2 . Note the short, broad hands, short middle long bones, and the ulna shorter than the radius. The vertebrae are almost normal. (D) Pedigree of the mild AMDM family.

the vertebrae were almost normal. This mild AMDM variant was distinct from Grebe and Hunter-Thompson type AMDs, as none of the clinical criteria specific for these two AMDs was observed in our patients, namely joint dislocations, ball shaped fingers, and fused or absent bones (table 1).

DNA extraction and microsatellite analyses were performed as previously described ${ }^{8}$ and primers of the chromosome 9p13-q12 region were chosen from the Genethon map. ${ }^{9}$ Homozygosity mapping was performed according to Lander and Bostein ${ }^{10}$ and two point linkage

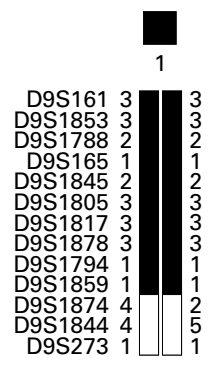

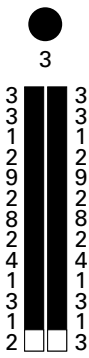

Group 1

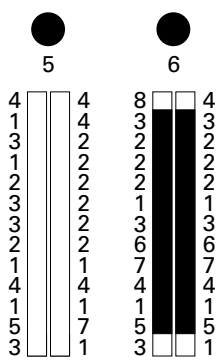

Group 2
Figure 2 Haplotypes of the affected subjects in typical (group 1) and variant AMDM (group 2) at the 9p13-q12 locus. Subjects 1 to 4 are the probands of four classical AMDM families (group 1). Patients 5 and 6 have a mild AMDM variant (group 2). The region of homozygosity is shown in black. The common region of homozygosity for group 1 is between microsatellites D9S1853 and D9S1874 (6.9 cM). Haplotypes of family 5 (group 2) exclude linkage to chromosome 9p13-q12 as the two affected subjects received different parental chromosomes in this region. analyses using the MLINK option of the LINKAGE package were performed according to Lathrop et al. ${ }^{11}$ The frequency of the disease allele was estimated to be 0.005 and penetrance was set at $100 \%$, assuming an autosomal recessive mode of inheritance. Inbreeding loops but not allele frequencies were taken into account as no controls were available for the population studied. The mutation rate was set at 0 . For homogeneity tests, the Morton likelihood ratio (LR) test was used. ${ }^{12}$

Linkage of the disease gene to chromosome 9p13-q12 was excluded in this family, as the two affected subjects received different parental chromosomes in this region (fig 2). Linkage of the family to the CDMP1 region was tested by using microsatellites at flanking loci D20S191 and D20S195 and an intragenic $[\mathrm{CA}]_{\mathrm{n}}$ dinucleotide repeat, ${ }^{13}$ but was inconclusive owing to a lack of informativity.

However, linkage analyses in four consanguineous AMDM families of Turkish and Lebanese ancestry supported the mapping of a gene for typical AMDM to chromosome 9p13q12 $(Z \max =3.27$ and $Z \max =3.23$ at $\theta=0$ at loci D9S1878 and D9S1817 respectively). All probands presented with clinical features typical of AMDM including severe growth failure ( $-5.5 \mathrm{SD}$ and $-7 \mathrm{SD}$ ) (fig 1A). The Morton likelihood ratio test supported genetic heterogeneity between typical AMDM and 
mild variants $(\mathrm{p}<0.01, \mathrm{p}<0.02$, and $\mathrm{p}<0.03$ for loci D9S1878, D9S165, and D9S1817, respectively).

The present study supports the mapping of a gene for typical AMDM to chromosome 9p13q12 and shows that mild AMDM variants are unlinked to this region. It is worth remembering that the existence of mild AMDM was suggested by Borrelli et al, ${ }^{14}$ who described a boy moderately affected with AMDM with a birth length of $50 \mathrm{~cm}$ and a growth pattern of -2.6 $\mathrm{SD}$ at the age of $2^{1 / 2}$ years. Studies of additional families with mild AMDM will help to confirm whether genetic heterogeneity indeed accounts for the variable clinical and radiological severity of the disease.

This work was supported by the "Coopération pour l'Evaluation et le Développement pour la Recherche", France. I Faivre is a recipient of a grant from the "Fondation pour la Recherche Médicale", France.

1 Maroteaux P, Martinelli B, Campailla E. Le nanisme acromésomélique. La Presse Med 1971;42:1839-42.

2 Langer LO, Garrett RT. Acromesomelic dysplasia. Radiology 1980;137:349-55.

3 Langer LO, Cervenka J, Camargo M. A severe autosomal recessive acromesomelic dysplasia, the Hunter-Thompson type, and comparison with the Grebe type. Hum Genet 1989;81:323-8.

4 Costa T, Ramsby G, Cassia F, et al. Grebe syndrome: clini$\mathrm{cal}$ and radiographic findings in affected individuals and heterozygous carriers. Am F Med Genet 1998;75:523-9.

5 Thomas JT, Lin K, Nandedkar M, Camargo M, Cervenka J, Luyten FP. A human chondrodysplasia due to mutation in a TGF- $\beta$ superfamily member. Nat Genet 1996;12:315-17.

6 Thomas JT, Kilpatrick MW, Lin K, et al. Disruption of human limb morphogenesis by a dominant negative mutation in CDMP1. Nat Genet 1997;17:58-64.

7 Kant SG, Polinkovsky A, Mundlos S, et al. Acromesomelic dysplasia Maroteaux type maps to human chromosome 9. Am F Hum Genet 1998;63:155-62.

8 Belin V, Cusin V, Viot G, et al. SHOX mutations in dyschondrosteosis (Leri-Weill syndrome). Nat Genet 1998; 19:67-9

9 Dib C, Fauré S, Fizames C, et al. A comprehensive genetic map on the human genome based on 5,264 microsatellites. Nature 1996;380:152-4.

10 Lander ES, Bostein D. Homozygosity mapping: a way to map human recessive traits with DNA of inbred children. Science 1987;236:1567-70.

11 Lathrop GM, Lalouel JM, Julier C, Ott J. Strategies for multilocus linkage analysis in humans. Proc Natl Acad Sci USA 1984;81:3433-46.

12 Morton NE. The detection and estimation of linkage between the genes for elliptocytosis and the Rh blood type. Am F Hum Genet 1956;8:80-96.

13 Lin K, Thomas JT, McBride OW, Luyten F. Assignment of a new TGF- $\beta$ superfamily member, human cartilagederived morphogenetic protein-1, to chromosome derived morphogenetic protein-1,

14 Borrelli P, Fasanelli S, Marini R. Acromesomelic dwarfism in a child with an interesting family history. Pediatr Radiol 1983;13:165-8. 